\title{
Gender and sustainable livelihoods: linking gendered experiences of environment, community and self
}

\author{
Wendy Harcourt ${ }^{1}$ (])
}

Accepted: 15 November 2016/Published online: 22 November 2016

(c) The Author(s) 2016. This article is published with open access at Springerlink.com

\begin{abstract}
In this essay I explore the economic, social, environmental and cultural changes taking place in Bolsena, Italy, where agricultural livelihoods have rapidly diminished in the last two decades. I examine how gender dynamics have shifted with the changing values and livelihoods of Bolsena through three women's narratives detailing their gendered experiences of environment, community and self. I reflect on these changes with Sabrina, who is engaged in a feminist community-based organization; Anna, who is running an alternative wine bar; and Isabella, a jeweler, who is engaged in ecofeminist practices. My analysis is based on concepts developed by feminist political ecology: specifically, the theory of rooted networks from Dianne Rocheleau, Donna Haraway's concept of naturecultures (and the work of J. K. Gibson-Graham on new economic imaginaries emerging from the politics of place. I aim to think with, reflect upon and provoke from the "otherwise", taking into account the lived relations entwining nature and gender. My article looks at the interconnections of gender, environment and livelihoods, attentive to the daily needs, embodied interactions and labours of these three women as part of a reappropriation, reconstruction and reinvention of Bolsena's lifeworld. By listening to the stories of their everyday lives and struggles, I show the dynamic potential of the politics of place and the efforts to build diverse economies and more ethical economic and ecological relationships based on gender-aware subjectivities and values.
\end{abstract}

Wendy Harcourt

harcourt@iss.nl

1 International Institute of Social Studies (ISS), Erasmus University Rotterdam, P.O. Box 29776, 2502 LT The Hague, The Netherlands
Keywords Feminist political ecology · Nature/culture · Bolsena

$\begin{array}{ll}\text { Abbreviations } \\ \text { EU } & \text { European Union } \\ \text { FPE } & \text { Feminist political ecology } \\ \text { NGO } & \text { Non-governmental organization } \\ \text { PdiV } & \text { Punti Di Vista, Points of View } \\ \text { WPP } & \text { Women and the politics of place } \\ \text { WWOOF } & \text { World Wide Opportunities on Organic Farms }\end{array}$

\section{Introduction}

The ultimate goal of feminist enquiry is to dismantle systems of oppression and eradicate the ideology of domination (hooks 1984).

I am writing this essay in Bolsena, a town of 4000 people on the shores of a volcanic lake in central Italy, located in Tuscia, an ancient Etruscan settlement at the borders of Lazio, Tuscany and Umbria. Bolsena was historically a small agricultural town, depending for centuries on agriculture and fishing for its livelihoods as well as patronage by the church and local landowners. In this essay, I explore the economic, social, environmental and cultural changes that have been taking place in Bolsena, as agricultural livelihoods have rapidly diminished over the last two decades. I look at how gender dynamics have shifted with the changing values and livelihoods of Bolsena, permeated by the quietly enduring dominance of the lake over the landscape.

Since the 1990s, there has been a dramatic decline of traditional local agricultural practices in the region, as agribusiness has taken over small orchards and gardens. This has created a threat to the livelihoods of small 
farmers, leading to abandonment of local farmland along with resistance to agribusiness and the globalization of food production as well as the emergence of new environmentally aware agriculture practices among small organic farms and cooperatives. As a result of these changing agricultural practices, there has been a growing reliance on tourism for most of the town's livelihoods. Consequently, seasonal tourism now dominates the town's rhythms rather than the agricultural seasons and has changed the local community, the lake and the area's environmental surroundings. What I would like to focus on here is how, in the last years, Bolsena has begun to host not only traditional mass and Church-based tourism but also alternative "eco friendly" tourist attractions linked to organic agricultural practices and new forms of arts and crafts inspired by the rich history of the area. Alongside these economic and social changes, there has been a growing environmental deterioration of the soils and lake, particularly marked by the problem of arsenic in the water, pollution of the soil and an increasing awareness and concern regarding climate change and "global" crises that have been infiltrating into this corner of central Italy. ${ }^{1}$

Here, with reference to three vignettes, I explore how gender relations have changed during these shifts in agricultural and other cultural practices, lifestyles and values. My analysis is based on concepts developed by feminist political ecologists-specifically, the theory of rooted networks from Rocheleau (2011), Donna Haraway's concept of naturecultures (2011) and the work of GibsonGraham (1996, 2006) on new economic imaginaries emerging from the politics of place-in order to offer some "otherwise" ways of understanding the changing gender relations amidst the shifting values and livelihoods of Bolsena. Inspired by Catherine Walsh, I will be "thinking with and reflecting/provoking from the 'otherwise'. That is the living thought and living relation of nature and gender which defy modernity's dichotomous binaries [in order to] fracture its universal claims, and make possible [...] an outside-otherwise" (Walsh 2015: 101). The article first presents feminist political ecology theory, followed by a methodological discussion, I then give the three vignettes from Bolsena life worlds and conclude with a discussion of the changing values and gender relations in Bolsena.

I use Bolsena "life worlds" to explore the nexus of gender-nature-society-relationships and how gendered subjectivities, ideologies and identities are shaping and contributing to our understanding of livelihoods and environments. By reflecting on these specific women's lives I aim

\footnotetext{
1 There are no scholarly articles written about Bolsena in English from a social science or political economy perspective, but some information can be gleaned from websites such as: http://www. bolsenanew.it or http://www.tusciatimes.eu or Wikipedia. See also Harcourt (2016).
}

to make visible how gendered embodied experiences are contributing to the Bolsena social, economic, environmental landscape. While the focus of the analysis is on gender relations as they are lived out in Bolsena my locally informed descriptions, observations and analysis link to a wider set of discussions of new Feminist Political Ecologies (FPE) (Rocheleau et al. 1996; Hawkins and Ojeda 2011; Harcourt and Nelson 2015). I build on recent "embodied, performative and/or post-structural theorizations of gender" (Elmhirst 2011: 130) which is creating "multiple imaginings and world-making" (Harcourt and Nelson 2015: 17). In writing about my reflections and engagement with Bolsena and its lifeworlds, I am not seeking to make claims about the scale of these encounters, but rather look at what these changing gender-nature-social relations suggest for new possibilities of world-making.

\section{Feminist political ecology: interconnections of gender, environment and livelihoods}

I take as my principle method of enquiry feminist standpoint theory, which examines the experiences of women in order to analyze how they experience and know differently from men, taking into account the intersectionality of gendered experience in its combination with class, race, age and other forms of difference (Harding 2004; Hill Collins 2009). Using feminist standpoint theory, I understand feminist research as both descriptive and normative when looking at the effects of power structures on knowledge emerging from shared lives. From this perspective, knowledge of the environment is understood as socially situated and residing in the narratives and understandings of those living, feeling and engaging in political and social power structures. Such feminist research seeks to draw out how gender is played out in power and knowledge relations (Haraway 2004).

FPE is interested in how the concepts of gender, power and knowledge permeate environmental and livelihood processes, analysing gender as a central social category that informs and shapes societal relations with nature, determining the allocation of different tasks and responsibilities between men and women as well as their different knowledges regarding nature and cultural relations. Gender is not an essential category determined by biology but rather a constructed phenomenon that is reproduced in and through practices, policies and actions that shift and change over time. Gender relations are shaped in dynamic ways by interactions with ecological, technological and politicaleconomic processes (Di Chiro 2008).

FPE particularly looks at how gender relations are produced through language, culture and performance (Butler 1990) while being embedded social, economic and cultural 
regimes of power in specific historic, ecological, geographic and political contexts (Rocheleau and Nirmal 2015). In examining gendered power relations in ecological, technological and political-economic processes, FPE helps highlight how gendered subjectivities, ideologies and identities are produced, contested, and employed around the governance of livelihoods and environments (Di Chiro 2008). Therefore, in seeking to understand how gender and environmental knowledge and practices interact, FPE emphasizes context (or place) rather than turning to universal or essentialist understandings of nature, culture and gender. Through such forms of interrogation, FPE maps out different "ecological imaginaries and understandings of places" that work from "diverse understandings and practices of sustainability", with a specific interest in practices that build "mutuality, reciprocity, and relationality" (Rocheleau and Nirmal 2015: 805).

Key to the FPE approach is "the search for good living, secured livelihoods and the 'sustainability of life' with a focus on interdependencies between people and ecosystems" (Wichterich 2015: 83). Sustaining livelihoods is about ensuring fundamental human requirements such as nutrition, ecological balance, clean water, secure housing, gender equality, and meaningful and diverse approaches to labour. This notion of livelihoods is key to a "lived feminist political ecology" approach (Harcourt and Nelson 2015: 13) that looks at how gender and environmental relations are experienced and felt as an important part of knowledge production around gendered ecological processes. For an FPE approach, therefore, livelihoods mean more than simply meeting economic needs and generating income but are also about "everyday interactions and embodiments and emotions" (Harris 2015: 158). This means that FPE is attentive "to everyday needs, embodied interactions and labours as well as emotional and affective relations with our environments and natures where we live" (Harcourt and Nelson 2015: 13) and aims, then, to start from the level of everyday life, through an embodied understanding of gender and environmental interactions.

As noted above, there are three writers whose conceptual work I have found particularly useful for my exploration of gender relations, changing environments and sustainable livelihoods in Bolsena. The first is the work of Rocheleau (2011), whose theory of rooted networks seeks to explain the material interdependence between people, places and other entities that shapes our "living worlds". Rocheleau seeks to explain how to understand relationships between people and places, recognizing how power and culture are infused within networks that are rooted in place. Her work proposes that we make visible how people conceptualize their relations to each other, beings and places in their living worlds or "life worlds".

Secondly, Donna Haraway's concept of naturecultures (2003) reiterates the intricate flows between nature and culture, highlighting the complex relationality that binds the two. She argues that "nature and culture are tightly knotted in bodies, ecologies, technologies and times" (2011: 9). By dissolving the binary opposition between the two constructs, she underlines their intrinsic connection, recognizing the "equiprimordiality of nature and culture" (Bauhardt 2013: 368). Such recognition of how closely nature and culture inform and shape each other is critical to developing an understanding of how gender relations are played out in livelihood practices (Kurian and Debashish 2003).

Thirdly, Gibson-Graham propose a way of moving beyond the common understanding of capitalism as omnipresent (Gibson-Graham 1996, 2006) and ask us to recognize how noncapitalist economic practices can allow new forms of economic imaginary to flourish. They look at community economies "in place", explaining that "[p]lace is a site of becoming and the ground of a global economic politics of local transformations where power is every day negotiated through ethical practices of freedom [...] Place signifies the possibility of understanding local economies as places with highly specific economic identities and capacities rather than simply as nodes in a global capitalist system" (Gibson-Graham 2007: 39).

Building upon Gibson-Graham, my understanding of the politics of place in Bolsena is critical to my analysis of the dynamics between gender and environment. Here I theorize place to mean what men and women understand as determining their livelihoods, being and identity - that is, body, home, local environs and community. My analysis of place derives from the "women and the politics of place" (WPP) framework (Harcourt and Escobar 2005), which "analyze[s] the interrelations created in women's struggles among body, environment and economies, in all of their diversities (diverse embodiments, diverse ecologies, diverse economies)" (Escobar and Harcourt 2005: 1). As with my previous WPP research on gender relations in place, my focus in this paper is on women's experience in Bolsena as, still, too often "the differences for women and men [have] become smoothed away in progressive analytical frameworks" (Escobar and Harcourt 2005: 2). The WPP framework looks at the differentiated notion of gendered political struggles in diverse places in the neoliberal global economy, anchored in the bodies, environments and economies of diverse communities of women in both affluent and neocolonial nations (Harcourt 2009; Sultana et al. 2016).

Bringing together the ideas of the above-mentioned feminist theorists, I analyze below in my study of women and the politics of place how the concepts of rooted networks, naturecultures, and new forms of economic imaginaries cohere together. This theorizing enables me to trace these efforts towards transformative politics, understood not so 
much as resistance but as "reappropriation, reconstruction, reinvention, even re-localization of places and place-based practices and the creation of new possibilities of being-inplace and being-in-networks with other human and non-human living beings" (Escobar and Harcourt 2005: 2). The aim of the article is to listen and learn from these women's lives with a sense of hope that changes in the Bolsena life world due to shifting natureculture relations are informed by feminist imaginaries that are at once rooted in place and connected by complex ecological, technological and political-economic processes (Escobar 2008).

\section{Methodological disclosure}

In writing about Bolsena, I am interested in investigating how gender relations are played out in changes in environment and society as part of my own search for more gender-aware, ecological and social justice. I look at the gender relations among local men and women and tourists, changes taking place in agricultural practices and the cultural and social histories being lived around the lake in order to explore the political landscape of Bolsena, which is at once uniquely local yet also linked to broader global imaginaries of economy and ecology.

My analysis in this essay is based on several years of direct observation, engagement and conversation with people involved in different projects in the region of Tuscia. Thus I am writing as both an insider and outsider. An Australian with Italian citizenship, I have been visiting Bolsena regularly since 2007. I work outside of Italy, so I visit Bolsena during holiday times and every other weekend. I am a member of a small community-based organization, Punti Di Vista (PdiV: Points of View), that works on gender, culture and food politics in Italy and internationally. In 2013, I bought a tiny house in the medieval part of the town, within the castle walls. I see myself as a marginal but permanent part of the ongoing life of the town, as a community activist and as one of the several residential "tourists" who have bought up the old picturesque houses that local citizens have left when they built the new "villas" on the old (disused) agricultural land around the lake and below the medieval town, perched on a hill. For my analysis, I have undertaken semi-structured interviews with three women working and living in Bolsena as well as drawn on my conversations with others involved in different initiatives in the Tuscia territory. This research has been undertaken "with" not "on" the women and others living in Bolsena. I have shared and discussed the ideas expressed in this essay with local groups in Bolsena while writing it and, as explained below, as a result we are planning further activist research in the region.
The vignettes of Bolsena "life worlds" that I share here seek to illustrate some of the diverse experiences of a changing political, economic and environmental landscape. ${ }^{2}$ In order to draw out some of the emerging "life world" practices in Bolsena, I relate three narratives based on the oral histories of three women, now in their early middle age, who for the last 20 years have been living and working in Bolsena. The first is about Sabrina and PdiV which is engaged with a small network of women in the region who work with their partners in alternative organic farming and food production. Another is the newly emerging cultural vision of Bolsena now being articulated in its cafés, wine, arts and music, as revealed through the story of Anna who, with her partner, runs a wine bar in the medieval castle area of Bolsena, linking local wine producers to a fledging Tuscian wine culture. And, thirdly, I look at the political and cultural organizing of the "women of the lake" through the experience of Isabella, a jewelry artist engaged both in environmental conservation work and in conserving/celebrating women's culture around the lake. Their lived, emotional and embodied experiences are presented in order to provide insights into how gendered practices of naturecultures, community economies and rooted networks operate in Bolsena.

\section{Sabrina and Punti Di Vista}

Sabrina is the President of PdiV, which has been collectively caretaking the seventeenth century Franciscan convent of S. Maria del Giglio ${ }^{3}$ since 1992 and is currently run by a core group of nine volunteer women and men (including Sabrina's husband from the US). Linked to this core group is a widespread network of activists, policy makers and researchers that use the convent as a retreat and meeting place. Summer volunteers come from World Wide Opportunities on Organic Farms (WWOOF) ${ }^{4}$ and help with the agricultural work as the convent has its own organic garden, vineyard and olive trees as well as goats and chickens, having the aim of being as self-sustaining as possible. PdiV also maintains the Franciscan tradition of using the convent as a resting place for pilgrims traveling the Via Francigena from Canterbury to Rome and as a nurturing place for seminars and retreats on environmental, gender and food politics.

\footnotetext{
${ }^{2}$ At the request of the three women I refer to them by their first names only. All the quotes are translated from Italian by the author and are taken from interviews held in August 2014.

${ }^{3}$ For more information about Punti di Vista, visit http://convento bolsena.org (Accessed 9 February 2014).

${ }^{4}$ A global organization that places volunteers in rural farms. For more information on "wwoofing", go to http://wwoof.net (Accessed 28 December 2014).
} 
Training sessions and workshops on local and global environmental issues are also held by PdiV, including ones on critical consumption and ecologically responsible waste reduction and management; gender and globalization; and sustainable local economies. In these ways, the organization aims to support the local Tuscia arts, food culture and history. It has hosted university courses, writing workshops, NGO meetings, art-therapy courses and well-being retreats, professional retreats, conferences of open-source software developers as well as many pilgrims. Since 2005, PdiV has focused its work on environmental concerns around food security, social justice and gender and has organized international, European and national workshops on food, agriculture, social justice and gender issues, partnering itself with academies (European Union and nonEuropean), research centers and NGOs.

The experience of the PdiV is imbued by the physical beauty of the convent, its efforts to sustain livelihoods and the contributions it makes to the local environmental and slow-food movements to battle for sustainable agricultural practices. When speaking to Sabrina about the PdiV's struggles to find economic resources to keep up the physical structure of the convent, it is clear that PdiV relies on the good will of its networks. Though rooted in Bolsena and deeply aware of what the landscape offers, PdiV has worked hard to become accepted by the Bolsenese community, overcoming the initial hostility of older members of the town who were upset when the Franciscan brothers in 1992 entrusted the convent to "foreigners", that is, young people in their 20s coming from Rome, $113 \mathrm{~km}$ south of Bolsena.

Sabrina describes how PdiV has built a sense of community through its international networks (to which I belong) and from engagement with people of a generation now, like her, in their 30s and 40s, living and working in the territory. When organizing meetings and events, she is careful to involve the services and produce of local food producers. She works in particular with various women of her generation who, with their partners, made the choice to leave urban centres and go back to the land in the 1990s. Especially nearby family-run enterprises, such as a goat farm, a beekeeper and sheep-cheese producers. These are educated people with some capital who were able to afford to make such livelihood choices in the search for a good life.

As Sabrina explains, Bolsena's location near Rome, its fertile volcanic soils and long agricultural history made it an appealing place for young couples to set up small rural enterprises. They came to the area fifteen or so years ago with a vision of sustainable farming practices and a healthier, better quality of life for their families, one that is more respecting of the environment than is possible living in urban environments. In our conversations, Sabrina reflects on her own choice to move from Rome to the convent in order to live a cooperative lifestyle in a rural environment, joined first by her husband and now her two small daughters. She describes it as a "political choice to provide my family with a better life and to live as sustainably as possible".

Sabrina's narrative focuses on how gender relations are played out in her own life and those of the other couples who she knows, observing that there are different experiences for men and women. As she puts it, "[t]hough both women and men have made the choice to go back to the land, sharing the vision of an alternative lifestyle to that of consumerism and alienation, changing gender roles do not form a part of this reexamination of the quality of life." She goes on to say that, even if both have decided to move to a rural environment when it is a couple, "it is the male partner who takes the lead in what is practiced on the farm - with the technical skills to handle the goats, run the bee houses, tend the goats or sheep who produce the cheese."

When elaborating further, she describes how a female organic cheese producer who is well educated-a former university teacher-has applied her communication skills and knowledge towards building the vision of a self-sufficient farm and creating what Sabrina calls "inspiring cheeses". This woman's skills enabled she and her husband to win a grant to set up a large goat farm with 70 animals. But, while she cares for the shop and administration tasks, her husband is outside tending the land, and raising the goats. On the honey farm, it is the man who has developed expertise and knowledge regarding local bees in the landscape (what flowers and plants to which they are attracted and where to bring the bees, etc.), and he has been happy perfecting and honing his knowledge over the years. In that partnership, it is the woman who deals with people and all the frustrations of registering the couple's products in order to keep the "organic" label. Not a job, Sabrina wryly comments, that anyone would see as being integrally part of the rural way of life.

Sabrina's observations about her life and others in the region point to how in this territory small organic enterprises tend to depend on women who are doing the management and the heavy load of bureaucratic work required to be organic food producers due to the imposition of the European Union of highly regulated (and expensive) standardization processes around production and hygiene. The women, she suggests, are also, at the same time, the ones doing the care work for the households and children and, in the end, feeling time constraints not so different from those of contemporary urban living. Ironically, Sabrina points out that it is often the women who were originally the more educated and financially richer partners, who made the necessary investments when the couples 
moved to the area. She states in our conversations that while the male partners speak of their pleasure and satisfaction in being closer to the landscape, the soil, the animals and plants, the women express how they are frustrated that they are not able to connect meaningfully with the rural environment, as they are stuck in the office while the men are outside. The women do the food processing, mostly indoors, while the men are involved in basic livestock production outside. The gendered division of labor also leaves the former to work on administrative tasks, chasing certification processes and dealing with the very complex Italian legal environment.

The assumption, based on Sabrina and other women's lives, is that the men are more appropriately working outside dealing with the environment and the women are suited to being inside, communicating with potential customers and efficiently dealing with bureaucracy. This observation by women living and working in Bolsena resonates with the study by Sachs et al. (2014) which explores how gender race and ethnicity influence where people work. The study looks at the spatial assignment among genders and race in rural US food work specifically examining who is working in the "front and back of the house" (ibid: 4). In their exploration of inequality regimes they pointed both to women prominently working in the "front of the house" dealing with customers and the detraditionalization trends in farming (ibid: 7). Although race and ethnicity is not in play in Bolsena, the gender divisions are similar. In Bolsena, women work, to borrow Sachs et al. metaphor at the 'front of the house' both directly and virtually, and men are working outside or the back of the house. While women in this Bolsena landscape do not express this in terms of lack of power or inequality, but rather as part of a transition move, they do state that they are not reaping the physical and emotional benefits of the move to the rural environment. As one woman said to Sabrina, she could be "anywhere" in front of a computer, filling in tax forms, paying service providers, dealing with clients and monitoring check lists required for annual registration as organic farms.

As Sabrina commented, in the bed-and-breakfast and eating establishments that she is in contact with regularly-establishments known as agriturismo, where tourists come to eat and sleep on farms- "it is the women who do most of the hard work producing fresh food and good cooking for the tourists." Sabrina also observes that there has been little change in gender dynamics and the gendered division of roles in these enterprises. The fact that women handle the financial side of the venture is new, but it does not seem to have come with greater decision-making power nor, most of all, more time to enjoy the rural environment in which they are living. As she describes it: "The women are less localized, losing out on their consciously expressed choice of wanting to belong to the place and in nature."

Sabrina provides insight into the embodied and emotional experiences of these specific men and women in the Region around the lake, in their search for a better life that embraces agricultural livelihoods. As well as offering a perspective on the intimate gender relations, and frictions, among these transplanted Bolsenese couples, she also speaks about the economic and technological challenges of organic farming. As Haraway's concept of natureculture indicates, there is no "pure" nature to which one can turn. The economic, political and social aspects of agriculture determine the lives of this small network of organic farmers nested in the landscape of Tuscia.

The network to which Sabrina and her contacts belong, could be seen to represent a new generation of men and women in Italy who are challenging agribusiness and globalization processes, in efforts to reconnect to nature and find clean spaces for themselves and their children (Brandth 2002). ${ }^{5}$

In order to live in healthier environments, they simultaneously have to deal with the negative impacts of globalization in their daily lives. As organic agricultural entrepreneurs, they are up against the global commodity market and are in competition with much lower prices from other producers, due to subsidies from the Italian state and the EU to the agribusiness sector. Food-safety regulations and fiscal constraints are also major challenges for these small-scale enterprises.

In addition to such obstacles, they also have to deal with the transformation of weather patterns that has come with climate change-still something not well understood-and shifts in ground soils, as organic farming practices now have to try and reverse the impacts on local soil and water from pesticides and other chemical products in use in the area since the 1930s. These constraints threaten the survival of these organic enterprises, and the question of how resilient both the enterprises and the couples are, given current economic and climate crises, is often raised in our ongoing conversations.

The difficult economic, and more recently climate, situation leads to strong political views and struggles against the state and EU control of their lives. As Sabrina says, "there is a common element of anarchism and organizing around concepts such as food sovereignty, slow food, degrowth, permaculture and other 'alternative' ways of rural living that oppose standardization and global agribusiness entering the territory". She also mentions

\footnotetext{
5 Sabrina and others among the active members of a Permaculture group in Bolsena who have hosted in September 2016 the first European Permaculture Festival which aims to 'harmonize the natural habitat with human settlement' see http://www.eupc.it for more information (Accessed 11 September 2016).
} 
political environmental groups in the territory that oppose genetic modification of seeds, illegal dumping of waste and environmental pollution has shown to be damaging peoples' health (Mosello et al. 2004: 11).

In our discussions on gender relations in these local political initiatives, Sabrina confirms what Counihan (2014) has argued: that, for example, the internationally known Slow Food movement-begun in Rome in 1986 and aiming to "defend regional traditions, good food, gastronomic pleasure and a slow pace of life" 6 -is not gender aware. As Sabrina puts it, "Slow Food is dominated by a male-centred vision." Though she sees this slowly changing with more gender-aware events, such as the large annual conference Terra Madre, it is still dominated by men, particularly in the local sections of the Slow Food movement in Italy.

When I asked Sabrina about her vision of gender equality for rural environments such as Bolsena, she stressed that she did not agree with the push by some environmentalists to go back to old traditions that eschew modern technologies in the home, as she sees domestic technology being necessary for freeing women's productive time. As Sabrina underlined, "washing machines are important for cleaning clothes and for those that don't want to use throw-away diapers." The problem is the built-in obsolescence of such technologies, so it is a structural change that is required, not more work for women in the homes, canning, washing clothes by hand and so on. Her vision of new values in agricultural life would be to move away from a focus on economic growth and, instead, to look at quality of life and take into consideration pleasure along with care of the Earth, of other lives - plant, animal and human. For her there should not be a "romanticizing of rural life [...]. A move back to the land to gain quality of life means rethinking the consumption imperative of our modern life."

Sabrina and I over time have spoken often about the discussions and actions we have joined taking place among those living in Tusica regarding "living slowly", reflecting on degrowth and alternative lifestyles based on values of care for the Earth. Sabrina is concerned that many of these discussions do not take up the gendered component of these new social forms. For example, near to Bolsena there is a transition town (Connors and McDonald 2011) ${ }^{7}$ where Sabrina observes that women tend to do the support work while they remain in the background of meetings and discussions. In contrast, men take the floor and see themselves confidently as the opinion leaders. She points out

\footnotetext{
${ }^{6}$ For more on Slow Food, see http://slowfood.com/international/7/ history (Accessed 14 August 2014).

7 Transition towns are part of a grass-roots, peak oil/climate change adaptation movement centered on local community organizing and action. For more on the transition movement see http://www. theguardian.com/environment/2013/jun/15/transition-towns-way-for ward (Accessed 12 December 2015).
}

that, "during the transition town festival, it is women who are doing the cooking and cleaning, men moderating and doing the talking. The gender division of who is doing what-who is doing the productive work and reproductive work in agriculture, and in the homes, turning the food into meals. All this lack of reflection is a big unsaid in all these groups." Her concern about these alternative movements and struggles is that, with so few women's voices being raised and heard, there is very little attention given to the need to change gender roles, and she suspects that "the men feel that progressive groups do not need to talk about reproductive work and gender divisions."

Sabrina runs a personal campaign around organic soap-a major local environmental concern, given the impact of chemicals on the water and soil around Bolsena. She presents certified clean soap as a gender issue as well as one that goes to the heart of consumer culture, as it requires changing consumer habits to understand that the "fresh" smell of clean sheets is the smell of chemicals. Alternative soaps are around but are more expensive. For the convent, she has introduced certified natural soaps and uses vinegar and other natural herbal cleaning agents, though as many visitors comment it does not smell "clean" to the modern nose. Similarly, she points out that permaculture is seen as untidy, though it is much better for the environment than mainstream agricultural practices.

Her campaign is part of trying to improve the environment in Bolsena. There is a slow poisoning of the lake taking place, due to waste and chemicals from agricultural production over the years and, more recently, changes to the watershed, as soils were added to the lake area to allow for new housing for tourists-but little is being said about this openly, as the fear is that it will scare off the tourists. She is concerned that there is not enough education and awareness regarding the danger of modern chemicals in Bolsena's soil and water and that economic imperatives are driving unhealthy and unsustainable environmental practices. Moving towards more environmentally aware values and concerns is also being taken up by other women engaged in new enterprises in Bolsena that are seeking to build ecotourism based on the richness of a soil that can produce good food and, also importantly for Italian culture, good wine if the soil degradation can be halted.

\section{Anna and the AENOS Enoteca}

Anna has been living in Italy since 1983. She came to Bolsena in 2007 in order to set up a wine bar with her partner, Sandro, called Aenos Enoteca ${ }^{8}$ where they sell and

\footnotetext{
${ }^{8}$ See the description of the wine bar at http://aenosbolsena.it (Accessed 28 December 2014).
} 
promote wine grown by small producers in vineyards situated mostly around the lake (Grotte di Castro, Gradoli, Montefiascone) as well as other winemakers in the Tuscia region. She is enthusiastic about wine as a product "eflecting the personalities of the people who are producing it and the soil where it is grown". As Anna explains, there are many ingredients that make Bolsena a good place for agriculture and fine quality wine production: the vineyards benefit from the fertile volcanic soil and slopes as well as the angle of reflection of the sun and light winds.

What she notes less enthusiastically is that agricultural land is being taken over by new modern settlements, sprouting up to cater to holiday-makers. Consequently, there is now much unused land, whereas once it was full of vegetable plots and orchards. She sees little interest in young people from Bolsena in keeping up rural agricultural traditions, and people who are interested in doing something new tend to come from outside Tuscia. For example, the cooperative supermarket is originally from Tuscany, and most of the organic farmers are not local people from Bolsena. As Sabrina also mentions, it is younger people from outside who are moving into the area and growing new wines in the lake region-in Grotte di Castro and Gradoli-using bio-dynamic methods to enrich the soil and helping to build an organic wine culture there.

Anna is conscious that she is not a local person, nor ever could be. She was born in Germany and, despite her 30 years in Italy, feels that she remains on the outside, though she does note that her Italian-born sons feel more Italian than German-even if both are presently in Berlin due to lack of jobs in Italy. As a writer and host of the wine bar, she is a vital part of the changing agricultural values and practices in Bolsena, helping to establish a growing network of people around wine who are rooted in knowledge of the soils, grapes and local culture of the lake.

But Anna also recognizes the gender divisions in her partnership. As Sandro is from Bolsena, this means he has local knowledge that is innate to their business, especially regarding who is who in the town, in the decision-making circles and the bureaucracy. Unlike the organic farmers mentioned by Sabrina, however, Sandro does the accounts. Anna is the one who does the cleaning and prepares plates of local cheese (bought from the organic farm owners mentioned above) to go with the wines they serve, playing a traditional feminine role. But, at the same time, she takes the lead in communicating and networking. She does the buying and sampling with local wine merchants. She brings to the enterprise her knowledge of languages and skills in modern communications, keeping up the website and marketing, including the writing of short novellas about the townspeople. Though it is not a traditional Bolsena partnership (which both emphasize) it is part of the "new Bolsena", where women are much more engaged in their enterprises as partners and not just shadow support. Together, they present themselves as hosts of the bar to promote the tradition of the ancient history of wine that brings local Bolsenese together with international visitors promoting an Italian and Mediterranean wine culture that has been in the region for thousands of years.

When speaking about the wine, Anna mentions other gender divisions in its production. The wine maker-the enologo - the person who decides on the construction of a wine, including which types of grapes to mix and in which quantities, is nearly always male. At the same time, Anna notes a change in gender dynamics, mentioning that a new generation of women is emerging that is engaged in organic wine production. Anna notes that, in the last 20 years, wine producers in Italy have gained a stronger presence of women than perhaps other agricultural products. She mentions the Associazione Nazionale Le Donne del Vino (The National Association of Women Working with Wine), founded in 1988 by Elisabetta Tognana, which now has 650 members, including famous wine-making names such as Antinori and Lungarotti, as well as Mazziotti from Bolsena. ${ }^{9}$ To Anna, this development "indicates that daughters have taken over the family businesses and are running them very successfully", though, she adds, "none of the men are probably in the back doing the administration and cleaning".

Anna underlines that wine culture is complex: it is not only about production but also about pleasure. It is, she describes, "a soft means to forget yourself and transgress [...] enjoy being part of humanity as, in the spirit of Bacchus, people let go as the wine helps them to open up to new ideas, liberate their imagination and communicate easily with people." She sees her role in Aenos as accompanying people on a journey of deeper connection with themselves as they enjoy the wine. When questioned, she describes the different experiences of men and women on this journey, seeing women as "more body-minded, more sensitive to what the wine is doing to them. They smell the wine better, their sense of taste is more developed than men $[\ldots]$ they are more open to the effect of what wine gives you. [...] Men are not so aware of the impact."

Anna describes their wine bar experience as building a new culture in Bolsena that is not about cheap consumption of wine but rather about promoting what she calls "complex wine and elegant ambiance". For this elegance and distinctly high quality, wine people who are generally not from Bolsena come to the wine bar, valuing the atmosphere as much as the wine. Both Anna and Sandro are aware of how different this vision of drinking wine as a "cultural"

\footnotetext{
${ }^{9}$ For more on the National Association of Women Working with Wine, go to http://www.ledonnedelvino.com. (Accessed 20 January 2015).
} 
activity is different from what old traditional Bolsena was about: the territory of fisherfolk and peasants who drank to drink, forget and survive.

Anna speaks of the difficulties of trying to bring about this kind of cultural change in the landscape of Tuscia. Aenos has chosen to engage in quality production and a resulting quality of life. However, locals, she comments, find Aenos too expensive. She mentions Serena from Bolsena who works in organic food and wine. Serena set up an organic wine bar, La Svolta, in the town of Orvieto, which closed down after 3 years of effort. The reasons for the closure that Anna mentions were high taxes and the difficulty of building up customers who were willing or able to pay for highquality wine and organic food. Reflecting on her own more successful experience in Bolsena, Anna explains that it is due to the number of foreigners who come to her wine bar, who are willing to pay higher prices that allow her to keep to high quality standards, such as using good crystal glasses, with a focus on presentation and professionalism. Anna speaks of the difficulties she has encountered with locals in terms of accepting this choice. She sees them as "people who live in the past" and are "unwilling to change". Tourism, she feels, is inevitable for the survival of the town, and she thinks it can be positive if enterprises encourage tourism that does not damage but rather supports Bolsena as a uniquely beautiful place, both culturally and environmentally.

Her description of Bolsena wine culture-the interlinkage between what the physical environment offers and its interplay with culture-illustrates Haraway's understanding of natureculture as well as the tensions and frictions within a rural way of life undergoing rapid changes. Talking to the younger people engaged in different enterprises in Bolsena, including young women producing wine and running small enterprises, it seems younger people are interested to part of the "new" world of Bolsena, based not on "making money" from tourism or agricultural production but on balancing a "good life" which can be rooted in the possibilities of the richness of Bolsenese natureculture.

Because it is not all about "making money" but about respecting "other" values (while still needing to live), Anna sees Aneos as a risky enterprise. Nevertheless, it is supporting other entrepreneurs in the territory's fledging wine industry, such as Le Lase, a winery run by four sisters producing very good wine named after Etruscan goddesses. This network is deeply rooted in the landscape, where wine producers, sellers and consumers speak with knowledge (and pleasure) about production and presentation processes.

As with Sabrina from PdiV, Anna points to administrative difficulties in trying to make these changes flourish. The barriers to change include a bureaucracy that she describes as, "amazingly complex for 4000 habitants [...] it takes years to get permission for work to change something small". She spoke, for example, of how almost impossible it was to get permission to have small wooden seats placed outside the bar, which took 4 years to achieve, and also to have a piano playing in the bar, which required official measurement of decibels, time restrictions and certificates. Predictably, she says, the Mayor of Bolsena, who owns a number of the hotels on the lakes, has no equivalent problem with making changes to his buildings or their playing music. Anna is also upset at the lack of support of Aneos from the town administration, who insist on time-consuming bureaucratic procedures with little care about whether the business survives or not.

The power issues implicit in these observations echo PdiV's Sabrina's narrative about organic farming and demonstrate how embedded power is in the technological everyday practices surrounding agriculture. Each politician and bureaucrat wields his or her, mostly still "his" in Bolsena, power.

When we spoke about the possibility of change, Anna commented with feeling on the deep conservatism of the place, with the people who are in their 60s being stuck in values set out by the Church and local politics. While she sees few Italian women of her age (in her late 50s) taking initiatives, she has seen more younger women (40 and below) becoming engaged in enterprises such as the wine growers mentioned above. She spoke of a photo festival held in Bolsena, organized by women in their 20s, and a 30 year-old woman's new family-run patisserie. But she also mentioned the sexism embedded in Italian politics, both locally and nationally. Anna argues that not only do women find it hard to enter local politics, but those who do are subject to sexism. She described, for example, a 2011 campaign for Berlusconi's party where the female Popolo della Liberta deputies, called Le Governiade, were photographed in sexy (semi-nude) poses with the pictures made into huge posters that were put up in front of the tourist office in the main square. Such observations are echoed in Italian feminist journals and writings. ${ }^{10}$ Anna speaks critically of sexism in Italian politics, even if she still sees possibilities for women to enter into the politics of place in Bolsena, in order to helps shape a more sustainable economy and community. In this she is joined by other women in Bolsena who are seeking to form strong womencentred values to inform everyday practices.

\footnotetext{
10 See http://www.retedelledonne.org/mappatura/\%20/riviste-femmi niste (Accessed 11 September 2016) For a list of the different feminist movements that are fighting for greater political representation and equality see Liste D http://tuttenoi.it/tuttenoi-web/lista-d-atti vismo-associazioni-reti-donne-italia/ (Accessed 11 September 2016).
} 


\section{Isabella and Le Crogiolo}

Isabella arrived in Bolsena 1991 from Rome, leaving behind her marriage and job. She was drawn to the area because of her maternal grandmother, who comes from Gradoli, which is the next town around the lake, $12 \mathrm{~km}$ away. Isabella when she arrived in Bolsena was the first woman to open a business in the castle area and, as she reminisces, as a single mother she had to be defiant in the face of local Bolsenese disapproval. She came to Bolsena in order to find a new way of life in the rural setting. During the first few years, she lived with her daughter in a tiny house that overlooked the fields where she imagined her grandmother would have worked. Over the course of the years, and with the help of a legacy from her grandmother, she set up a jewelry shop with windows overlooking Lake Bolsena called Le Croglio (The Crucible). She has related strongly to the landscape as well as to the possibilities it offered for a life based on what she calls "feminine" values, finding strong friendships and collaborations with other women who have arrived in Bolsena over the years, also in search of a better life away from the urban bustle. She gradually built up her jewelry business and network, reconnecting with the territory and taking economic risks that have paid off.

Her jewelry business reflects her search for new values in the lake area, which could be seen as being ecofeminist, though she does not use this term herself (Gaard 2011). With artistic flare, she has taken images from the Etruscan culture that existed around the lake before the Romans, creating Earth-goddess jewelry in silver and semi-precious stones. Her jewelry explores images of powerful goddesses and evokes strong spiritual meanings linked to the wellknown teachings of shamanic healer Nobel (2003), who has visited Bolsena.

Isabella sees her jewelry as a celebration of the feminine culture that enriches and changes the Bolsena landscape. Her customers are local as well as from out of town. There are now other similar ventures in Bolsena and around the lake. Women work in small outlets, selling fairtrade clothes and locally designed products, in a network of female-run enterprises of arts and crafts with a spiritual and collective feel to them. Isabella's jewelry is on display in these other shops in the medieval part of Bolsena, below the castle. However, increasing taxes and a slowing down of the tourist trade due to on-going economic crisis means that Isabella closed down her workshop in September 2014 and converted the shop into a studio and centre for female artists in the territory. She sees this as a way of moving on from a solo adventure to joint collaboration with female artists, potters, and dressmakers and speaks enthusiastically about courses she will attend, given by a shaman, to deepen her knowledge of Etruscan history and the goddesses of agriculture of the Tuscia region.

Isabella, like Anna, is part of the community in and around Bolsena that sees itself as creating "slow" culture. As this idea of the new venture suggests, Isabella has an extensive network around the lake of women, and men, with whom she works and enjoys the social life of the territory. She takes an active part in the cultural festivals of the small towns in Tuscia, all of which have annual special processions and fairs historically evolving from the Roman days or earlier. Isabella is also a member of the committee that set up a summer Italian-film festival in the castle area of Bolsena.

Although she has a partner-a biodynamic baker who lives in a smaller township about $20 \mathrm{~km}$ from Bolsena to Isabella fiercely values her independence and her role as a mother. She feels that her choice to move to Bolsena has, in the end, provided a secure and good life for her and her daughter, who has now completed her university education and is working as a photographer and clown in Viterbo, coming back occasionally in order to support local events in Bolsena, such as the photography exhibition mentioned above.

Isabella's current collaborations include a goddess project with Katia, who runs Le Sorgenti (The Source), an eco feminist bookshop and slow-food restaurant in the medieval part of the town, where the community group Le Donne del Lago (Women of the Lake) meet. The group has a strong ecofeminist and spiritual flavor, as they raise concerns about the wellbeing of Lake Bolsena. They are worried about the growing pollution of the lake, which has high levels of arsenic as well as chemical waste from the fields and hotels and, therefore, campaign for greater awareness regarding the lake's health and preservation. They deliberately work on the margins of local politics and bureaucracy, advocating for greater public funds to address ongoing environmental damage due to bad management and poor technical maintenance of the three pumps around the lake.

Isabella is also part of another local women's group: Compagnia delle Lavandaie di Tuscia (Tuscia Laundry Women). The Lavandaie was founded by Simonetta, who has revived songs of the nineteenth century washerwomen of the Tuscia region, who traditionally washed the clothes of the local nobility and wealthy farmers in the two stillexisting public baths in Bolsena. The songs encouraged them to work together by keeping rhythm. The group celebrates the history of such popular songs and "the art" of washing clothes in these public laundries. Their aim is to give value to the traditional work of the territory with traditional instruments and costumes, singing local songs, nursery rhymes and popular ballads from Bolsena. The group, made up of around 20 women living in Bolsena (two of whom are actually from the families of washerwomen), 
not only perform in Bolsena but also attend festivals across the Tuscia region as well as other towns in Italy and have even gone further abroad to Germany. They dress in white linen and lace with head scarves and long skirts and, during tourist season, are often seen around the town squares. They have produced a calendar with themselves singing and washing in the open washing baths, which they sell to raise funds to support their attendance at local festivals in the region.

Isabella's engagement with the Lavandaie reflects her strong, what she calls "feminine" values related to the historical natureculture of Bolsena. She sees them as being important for reclaiming women's contributions to everyday survival strategies-ones that she wants to learn from as she creates a new artistic space in the castle area.

\section{A feminist political ecological analysis of possibilities in light of changing values and gender relations in Bolsena}

These three vignettes, suggest how gendered power relations are being lived and produced through the performance, engagement and production of culture linked to the specific livelihoods and geographical/historical landscape of Bolsena, embedded within existing socioeconomic and socio-cultural regimes of power. Taking the example of the Lavandaie as gendered performance, we can see productive tensions among the different women interviewed. My interviewees attributed different levels of importance to the Lavandaie and what the group means for gender relations in the town. While Isabella, as a member of the group, sees the Lavandaie as being central to Bolsena's lifeworld, raising public awareness of water as a feminine (rather than feminist) issue, celebrating women's culture and the "art" of washing, Sabrina and Anna were not so sure whether this should be construed as such a powerful or positive image. Anna sees it as celebrating not the power of women's culture but rather the exploitation of women, regarding the group as faintly ridiculous. Sabrina, though more supportive of the group and considering that it may be good to have an all-women's group in the Tuscian folk festivals around the lake, wonders about the political image they represent. She suggests they are going backwards not forwards in terms of women's position in the town. For Sabrina, they do not challenge enough the stereotype of the "good women" who passively wash clothes and sing songs, though she sees them as also rescuing important everyday histories of the culture of women's lives in the area. She is nonetheless concerned that it reinforces the ideas of the "slow-food men" who welcome the handwashing of clothes-by women-as part of a new ecological lifestyle. The attitudes of men in Bolsena towards the group are hard to read. A recent addition to their performance has been local men dressing up as washerwomen and following them around in a kind of burlesque, adding to the fun but, somewhat undermining and perhaps making light of the intent of celebrating women's work.

The interviews point towards different gendered experiences among the various people and activities observed in Bolsena: the couples running organic farms in the area; the frictions with the local bureaucracies and politics; and the attempts of women to organize to save the environment around the lake and reproduce Etruscan art. These everyday activities highlight how gendered subjectivities, ideologies and identities are produced and contested in the Bolsenian experience and search for healthy livelihoods and clean environments. They illustrate how the search for a good life in rural agricultural environments that are challenging local hegemonic political and agricultural practices is not easy, particularly for women like Anna, Isabella and Sabrina, who are considered outsiders to Bolsena. As they, together with their partners and networks, have taken on the search for new values and new cultural and agricultural practices in the territory, they are seen as contesting the mainstream practices now dominated by agribusiness, church and state.

There is, however, evidence of values changing in a positive direction for gender roles in the natureculture of Bolsena. In the face of contemporary economic, political and environmental (climate) crises, there is hope in the slow culture emerging in Boslena. What is interesting here is how the experience and knowledge of the women is rooted in place and its histories as well as an understanding of changing global ecological, technological and politicaleconomic processes. The changes in food and wine production, environmental and cultural practices and cultures are part of a dynamic process of natureculture in the Bolsena lifeworlds. The organic agricultural practices of making cheese or honey, the creation of an organic wine culture, the performances of the Lavandaie or the advocacy for natural soap and campaigning by women to prevent the lake's pollution, contribute to the changing natureculture of the landscape and form a part of the socio-environmental knowledge of the place.

These women's lives also speak to evolving economic imaginaries based on the practices of gender labour and relations with changing economic possibilities. The differently gendered experiences are part of the creation of emerging alternative visions of the economy and ecology. The everyday practices of caring for goats, making cheese, doing the accounts, providing hospitality for pilgrims, singing nineteenth century songs, or creating occasions for people to enjoy and learn more about the organic wine of 
the region suggest the forming of new values and imaginaries that are grounded in the search for wellbeing away from urban settings. As Gibson-Graham's writings indicate, this search is gendered, as these women are seeing, caring for and valuing the landscape in different ways from the men with whom they interact, including their partners. Even if the women in Bolsena do not use the term feminist, their role can be looked at as an evolving ethical economic prototype. At the same time, there is also a coming together of the genders in the resistance to conservative traditions in Bolsena and the obstacles imposed by the economic and political power of local, national and European authorities. The women speak of their embodied and emotional attachment to the town, the lake, the Tuscian landscape and the culture they are creating while changing the old divides of urban/rural, as they intertwine different modern technologies of communication and historically bound material realities in their livelihood activities and practices of enjoyment.

In the above vignettes, women speak of transformative and emancipatory opportunities that are responses to economic and political struggles around resources, knowledge and territories, illustrating Rocheleau's analysis of rooted networks. These are small transformations, grounded in care for the physical and social environment of Bolsena evolving over time and within the territory. Such transformation is not linear or necessarily able to be scaled up, as such, but are creating new lifeworlds as people move towards more sustainable livestyles, responding to the shifts and producing, as Gibson-Graham suggest, alternatives to a capitalocentric logic of the state and the church. These practices are disrupting politically and socially conservative elements in Bolsena, and could be seen as representing new values for care of the community and the environment, along with diverse forms of spirituality and creativity.

In describing the naturecultures of Bolsena, the formation of the rooted networks and different economic imaginaries in place, I look at these three women's understandings of their lifeworlds as part of the needed new narratives which are about the "reappropriation, reconstruction, reinvention" (Escobar and Harcourt 2005: 3) of our lifeworld rooted in the positive, the connections of people, other beings, the past and visions for the future. By listening to the stories of such everyday lives and struggles, we can see the dynamic potential in the politics of place, of a natureculture centred around the beauty of a volcanic lake, and the efforts to build diverse economies and more ethical economic and ecological relationships based on gender-aware subjectivities and values.

Open Access This article is distributed under the terms of the Creative Commons Attribution 4.0 International License (http:// creativecommons.org/licenses/by/4.0/), which permits unrestricted use, distribution, and reproduction in any medium, provided you give appropriate credit to the original author(s) and the source, provide a link to the Creative Commons license, and indicate if changes were made.

\section{References}

Bauhardt, C. 2013. Rethinking gender and nature from a material(ist) perspective: Feminist economics, queer ecologies and resource politics. European Journal of Women's Studies 20(4): 361-375.

Brandth, Berit. 2002. Gender identity in European family farming: A literature review. Sociologia Ruralis 42(3): 181-200.

Butler, J. 1990. Gender trouble: Feminism and the subversion of identity. London: Routledge.

Connors, P., and P. McDonald. 2011. The political economy of localization in the transition movement. Community Development Journal 50(2): 312-326.

Counihan, C. 2014. Women, gender, and agency in Italian food activism. In Food activism, agency, democracy and economy, ed. C. Counihan, and V. Siniscalchi, 61-75. London: Bloomsbury Press.

Di Chiro, G. 2008. Living environmentalisms: Coalition politics, social reproduction, and environmental justice. Environmental Politics 17(2): 276-298.

Elmhirst, R. 2011. Introducing new feminist political ecologies. Geoforum 42(2): 129-132.

Escobar, A. 2008. Territories of difference: Place, movements, life, redes. Durham: Duke University Press.

Escobar, A., and W. Harcourt. 2005. Practices of difference: Introducing "women and the politics of place". In Women and the politics of place, ed. W. Harcourt, and A. Escobar, 1-19. Bloomfield, CT: Kumarian Press.

Gaard, G. 2011. Ecofeminism revisited: Rejecting essentialism and re-placing species in a material feminist environmentalism. Feminist Formations 23(2): 26-53.

Gibson-Graham, J.K. 1996. The end of capitalism (as we knew It): A feminist critique of political economy. Oxford: Blackwell.

Gibson-Graham, J.K. 2006. A post capitalist politics. Minnesota: University of Minnesota Press.

Gibson-Graham, J.K. 2007. Economic imaginaries (Web edition). http://www.communityeconomies.org/site/assets/media/Katheri neGibson/Venice-gibson-graham.pdf. Accessed 24 Oct 2016.

Haraway, D. 2003. The companion species manifesto: Dogs, people, and significant otherness. Chicago: Prickly Paradigm.

Haraway, D. 2004. Situated knowledges. In The feminist standpoint theory reader: Intellectual and political controversies, ed. S. Harding, 183-202. New York: Routledge.

Haraway, D. 2011. 'Speculative fabulations for technoculture's generations: Taking care of unexpected country'. Australian Humanities Review 50(5): 1-18. www.australianhumanitiesre view.org/archive/Issue-May-2011. Accessed 23 Feb 2016.

Harding, S. 2004. Introduction: Standpoint theory as a site of political, philosophic and scientific debate. In The feminist standpoint theory reader: Intellectual and political controversies, ed. S. Harding, 1-16. New York: Routledge.

Harcourt, W. 2009. Body politics in development: Critical debates in gender and development. London: Zed Books.

Harcourt, W., and A. Escobar (eds.). 2005. Women and the politics of place. Bloomfield, CT: Kumarian Press.

Harcourt, W., and I.L. Nelson (eds.). 2015. Practicing feminist political ecologies: Moving beyond the green economy. London: Zed Books.

Harcourt, W. 2016. Place. In Keywords for environmental studies, ed. J. Adamson, W. Gleason, and D.N. Pellow, 161-163. New York: New York University Press. 
Harris, L. 2015. Hegemonic waters and rethinking natures otherwise. In Practicing feminist political ecologies: moving beyond the green economy, ed. W. Harcourt, and I.L. Nelson, 157-181. London: Zed Books.

Hawkins, R., and D. Ojeda. 2011. Gender and environment: Critical tradition and new challenges. Environment and Planning $D$. Society and Space 29(2): 237-253.

Hill Collins, P. 2009. Black feminist thought: Knowledge, consciousness, and the politics of empowerment. New York: Routledge.

hooks, B. 1984. Feminist theory: From margin to center. Cambridge, MA: South End Press.

Kurian, P., and M. Debashish. 2003. Negotiating human-nature boundaries, cultural hierarchies and masculinist paradigms of development studies. In Feminist futures: Re imagining women, culture and development, ed. K.-K. Bhavani, J. Foran, and P.A. Kurian, 146-159. London: Zed Books.

Nobel, V. 2003. Making ritual with the motherpeace cards. Rochester Vermont: Bear \& Company.

Mosello, R., S. Arisci, and P. Bruni. 2004. Lake Bolsena (Central Italy): an updating study on its water chemistry. Journal of Limnology 63(1): 1-12.

Rocheleau, D., B. Thomas-Slayter, and E. Wangari. 1996. Feminist political ecology: Global perspectives and local experiences. London: Routledge.

Rocheleau, D. 2011. Rooted networks, webs of relation, and the power of situated science: Bringing the models back down to earth in Zambrana. In Knowing nature: Conversations at the intersection of political ecology and science studies, ed. M.J. Goldman, P. Nadasdy, and M.D. Turner, 209-226. Chicago: University of Chicago Press.
Rocheleau, D., and P. Nirmal. 2015. Feminist political ecologies: Grounded, networked and rooted on earth. In The Oxford handbook on transnational feminist movements, ed. R. Baksh, and W. Harcourt, 793-814. Oxford: Oxford University Press.

Sachs, C., P. Allen, A.R. Terman, J. Hayden, and C. Hatcher. 2014. Front and back of the house: socio-spatial inequalities in food work. Agriculture and Human Values 31(1): 3-17.

Sultana, F., C.T. Mohanty, and S. Miraglia. 2016. Gender equity, citizenship and public water in Bangladesh. In Making public in a privatized world: The struggle for essential services, ed. D. McDonald, 149-164. London: Zed Books.

Walsh, C. 2015. Life, nature, and gender otherwise. Feminist reflections and provocations from the Andes. In Practicing feminist political ecologies: Moving beyond the green economy, ed. W. Harcourt, and I.L. Nelson, 101-130. London: Zed Books.

Wichterich, C. 2015. Contesting green growth, connecting care, commons and enough. In Practicing feminist political ecologies: Moving beyond the green economy, ed. W. Harcourt, and I.L. Nelson, 67-100. London: Zed Books.

Wendy Harcourt, Ph.D. is Associate Professor in Critical Development and Feminist Studies. She has edited 12 books and published many articles in the field of environment, gender and development. Her most well-known book "Body Politics in Development: Critical Debates in Gender and Development" (2009) London: Zed Books received the 2010 Feminist Women Studies Association Book Prize. 